\title{
DEFENSE MECHANISMS OF ARTHROPODS. XX. QUANTITATIVE ASSESSMENT OF HYDROGEN CYANIDE PRODUCTION IN TWO SPECIES OF MILLIPEDES ${ }^{1}$
}

\author{
By H. E. Eisner, D. W. Alsop, and T. Eisner \\ Division of Biological Sciences, Cornell University
}

Although much has been learned in recent years about the chemical nature of the defensive secretions of arthropods (for reviews see Jacobson, I966; T. Eisner and Meinwald, I966; Roth and T. Eisner, I962; Schildknecht et al., I964), virtually no precise measurements have been made of the quantities in which the active principles are produced and stored. In animals that discharge their secretion as a liquid, gland capacity may be estimated directly by weighing the amount of fluid ejected. But when the defensive substance is emitted as a gas, a more refined assay is in order. In two previous papers of this series, we dealt with the production of gaseous hydrogen cyanide by certain species of millipedes, and described the structure and mode of operation of their cyanogenetic glandular apparatus (H. E. Eisner et al., I963; T. Eisner et al., I963). We have now developed a quick and highly sensitive assay for hydrogen cyanide, and it is our purpose here to report on the measurement of cyanogenesis in two species of millipedes, Apheloria corrugata and Pseudopolydesmus serratus (Text-fig. I). Both are members of the order Polydesmida, the only one in which cyanogenetic species are known to occur.

Polydesmoid millipedes generate hydrogen cyanide only in response to disturbance. The poison emanates as a gas from droplets of secretion discharged by special glands that open along the sides of the body. Apheloria and Pseudopolydesmus each have a total of 22 glands, present in pairs on segments 5, 7, 9, IO, I2, I3, I5, I6, I7, i8, and i9 (Text-fig. 2). In Apheloria, each gland is a two-compartmented organ (Text-fig. 2). In the inner compartment (reservoir) there is stored an aqueous emulsion of mandelonitrile, the adduct of benzaldehyde and hydrogen cyanide. The other compartment (vestibule) contains a catalyst, presumably an enzyme, that promotes the dissociation of mandelonitrile. The gland is constructed

${ }^{1}$ This study was supported by Grant AI-02908 from the National Institutes of Health. We thank our colleagues, W. L. Brown, Jr., W. T. Keeton, J. Meinwald, D. S. Robson, and F. C. Steward, for helpful advice. The first three also read the manuscript.

Manuscript received by the editor May 22, 1967 


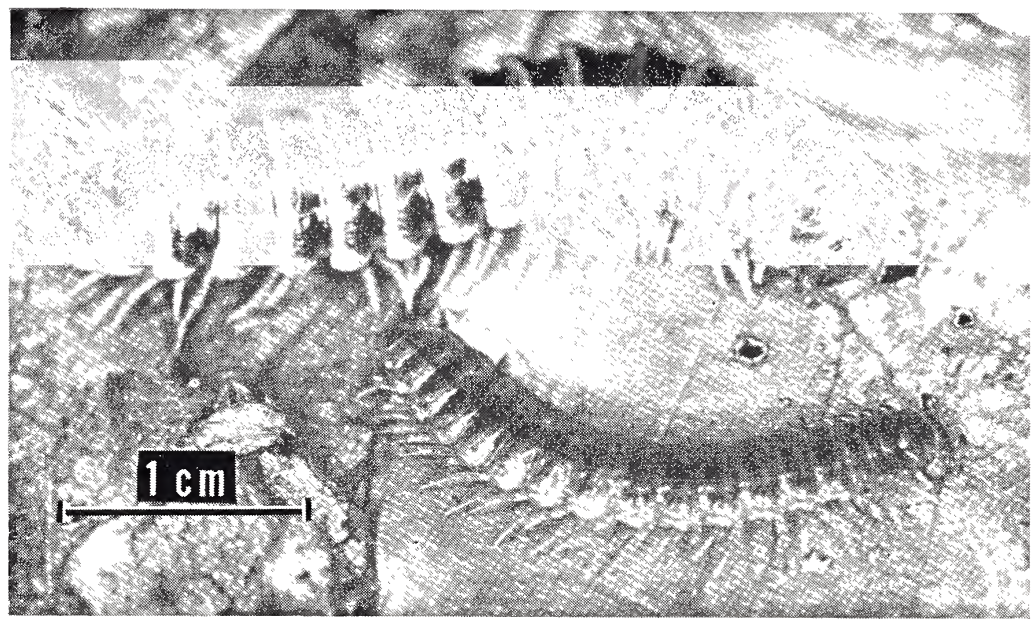

Text-fig. 1. Apheloria corrugata (above) and Pseudopolydesmus serratus.

in such a way that the contents of the two compartments are mixed, and cyanogenesis is initiated, at the instant of discharge. Cyanide liberation proceeds gradually, and persists for minutes after the discharge $(\mathrm{H}$. E. Eisner et al., I963; T. Eisner et al., I963). The secretion and its vapors are strongly repellent to predators ( T. Eisner and H. E. Eisner, 1965). Apheloria may discharge from one, several, or all glands, depending on the severity of the attack. A single ant, biting one of the millipede's legs, may cause only the gland nearest that leg to discharge, but this suffices to deter the assailant. A larger predator, or a swarm of ants, may inflict more generalized trauma and cause a number of glands to discharge. Ejection from all glands occurs only in response to unrestricted disturbance, such as rough handling. The preceding probably applies also to Pseudopolydesmus, which is known to generate hydrogen cyanide (H. E. Eisner et al., 1963), and which we have found to possess two-compartmented glands essentially similar to those of Apheloria. However, it is not known whether Pseudopolydesmus also generates hydrogen cyanide by dissociation of mandelonitrile. The fact that its secretion has an odor distinctly different from that of benzaldehyde suggests that it may store a cyanohydrin other than mandelonitrile or, alternatively, that its secretion contains additional compounds capable of masking the odor of benzaldehyde. 

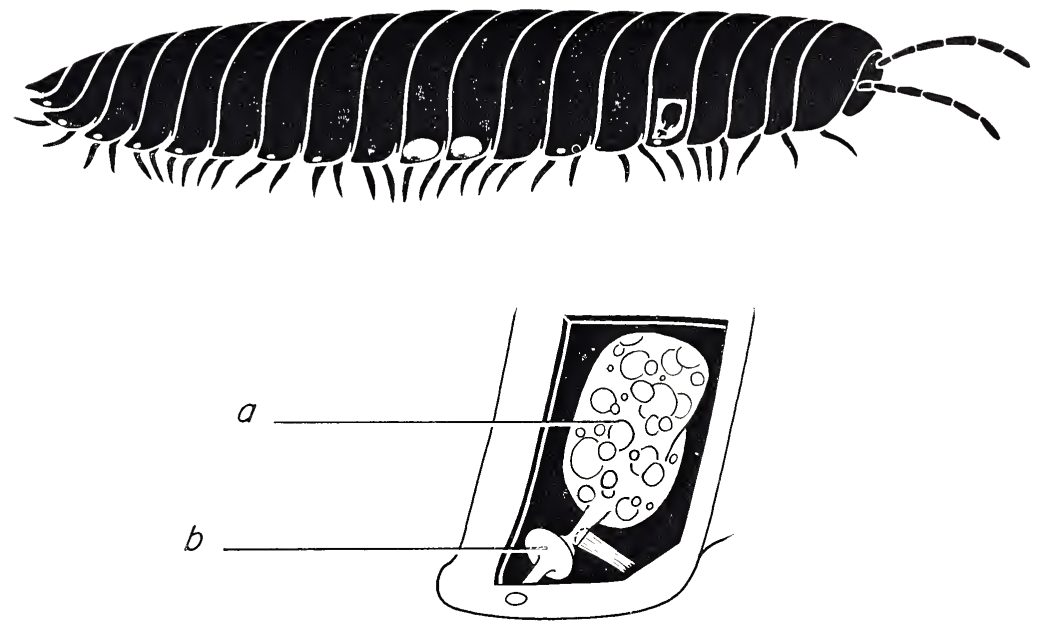

Text-fig. 2. Top, diagram of Apheloria, showing the gland openings (white spots) on the notal margins. Glands on segments 9 and 10 have discharged their secretion. The cutaway showing the gland in segment 5 is enlarged below. The reservoir of the gland (a) contains emulsified mandelonitrile. A valve operated by a muscle separates the reservoir from the smaller vestibule (b), which contains the catalyst.

Cyanogenesis in millipedes has never before been measured. However, naturalists have long been aware of the considerable potency of the secretion, and it had been noted that a container with cyanogenetic millipedes could serve as an effective "killing jar" in which insects and other small animals would not long survive ( $T$. Eisner and H. E. Eisner, 1965). We have found the vapors liberated by freshly disturbed Apheloria to be rapidly fatal to houseflies confined with the millipede in a small vial, and others have made comparable observations (Davenport et al., I952).

\section{MATERIALS AND METHODS}

\section{The millipedes}

Apheloria and Pseudopolydesmus were taken at Ithaca, N.Y., in an area of about an acre on a woody hillside beside a brook, in moist leaf litter and under rocks. They were collected at various dates throughout their active season, from early May to late November. They were assayed for hydrogen cyanide production within less than four days after capture. 


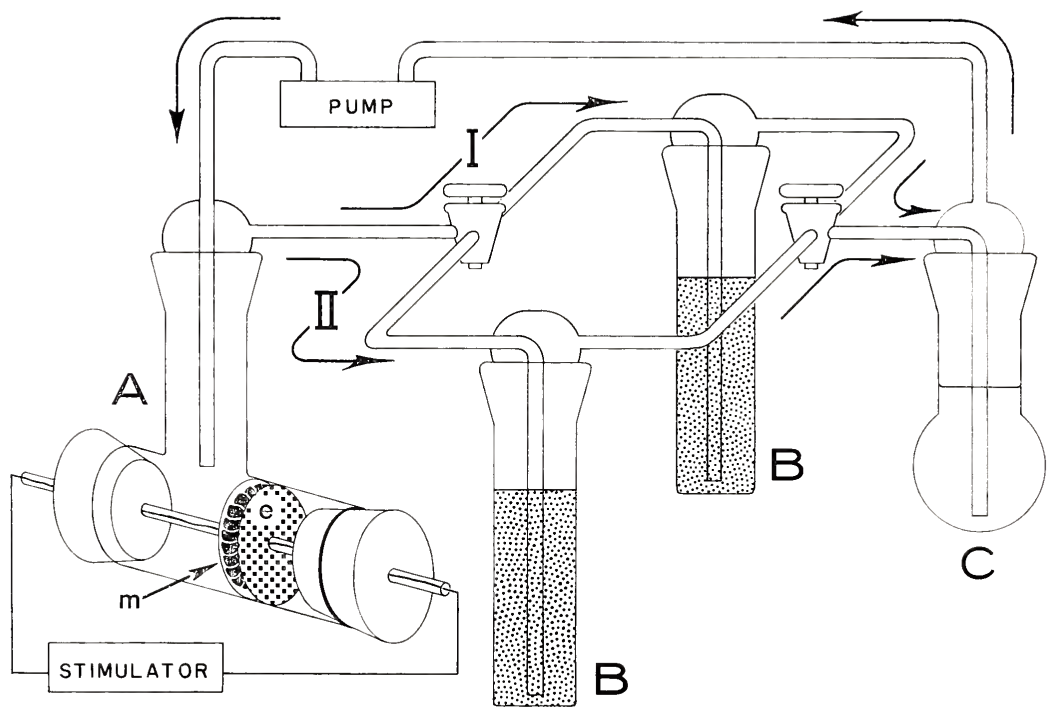

Text-fig. 3. Apparatus used to stimulate millipedes electrically and to trap the hydrogen cyanide liberated. Details in text.

Special precautions were taken to prevent millipedes from discharging prematurely before the assay. When first collected in the field, they were allowed to crawl into individual vials, and from the vials into cages, without being handled in the process. Under these circumstances they do not discharge, as was determined by introducing strips of filter paper impregnated with benzidine reagent (Feigl, I960) into the closed quarters of newily captured millipedes. The strips always remained white instead of turning blue, indicating absence of cyanogenesis. Likewise, in the Iaboratory, when the millipedes were transferred from cages into the apparatus used for the assay, the transfer was effected by way of vials without direct handling.

The assay

In principle, the assay for hydrogen cyanide is based on the fact (Denigès, I 895; Liebig, I 85 I ) that a turbid colloidal suspension of silver iodide in aqueous ammonia can be converted into an optically clear solution of silver ammonium cyanide $\left[\mathrm{Ag}(\mathrm{CN})_{2} \mathrm{NH}_{4}\right]$ by addition of hydrogen cyanide (or other sources of cyanide ion). For a given volume of suspension, the amount of cyanide that causes clearness is constant, and can be determined by titration. If an unknown quantity of cyanide is added (for instance, as hydrogen cyanide from 
a millipede), the amount of this unknown can be calculated by titrating the remaining silver iodide to a clear end point.

Text-figure 3 shows the apparatus in which individual millipedes were electrically stimulated to discharge and the emanating vapors of hydrogen cyanide were trapped for subsequent assay. A millipede was transferred into chamber $\mathrm{A}$, and the two grid electrodes (e), whose shafts fit movably through the stoppers at the ends of the chamber, were gently pressed against the animal (m) from both sides. Three electric shocks (0.5 v., $25 \mathrm{~Hz}$.) of $30 \mathrm{sec}$. duration, administered at 10 min. intervals, caused the millipede to discharge its secretion ${ }^{2}$. A pump circulated the gas in the system directing it first through one of two alternative pathways (I, II) bearing a cyanide trap (B) with a measured amount of standardized silver iodine suspension ${ }^{3}$, and then through a vessel $(\mathrm{C})$, containing aqueous sulfuric acid, which prevented ammonia vapors, flushed from $B$, from reaching and harming the millipede. Since a single trap rarely sufficed to collect all the hydrogen cyanide emitted, the gas was bubbled through a series of traps. This involved routing the flow in alternate succession through I and II, and replacing the individual traps with fresh ones for as long as their tendency to clear indicated the continuance of cyanogenesis. As a rule, cyanogenesis came to a halt within 30 to 50 minutes, but in animals of high yield it often lasted beyond the hour. The final assay consisted of pooling the contents of all traps, and titrating away the residual turbidity with standardized solution (o.or M) of sodium cyanide. The end point of the titration was determined photometrically (Bausch \& Lomb Spectronic 20 Spectrophotometer, set at $\lambda=500$ ), by comparison with distilled

\footnotetext{
${ }^{2}$ This triple stimulus was adopted as a standard after it was demonstrated (by preliminary tests in which individual Aphcloria were subjected to one or more shocks of varying intensity, frequency, and duration, and assayed for hydrogen cyanide production after each shock) that it was adequately strong to cause the animal to expel its entire secretory reserves. As a rule, the first shock sufficed to cause depletion or near depletion of the glands, which discharged visibly and usually simultaneously within seconds after onset of the stimulus. The second and third shocks evoked at most a very slight additional output of cyanide, indicating that the unexpelled residue had been minimal. Fourth shocks always proved superfluous. Specimens dissected after electric stimulation had empty glandular reservoirs. The electric shocks did not noticeably harm the millipedes, which survived as long as untreated controls (usually from two to five months).

${ }^{3}$ The suspension was prepared from silver nitrate $(0.001 \mathrm{M})$, concentrated aqueous ammonia (ca. 25\%), potassium iodide $(0.005 \mathrm{M})$, and distilled water, mixed in the ratio of $10: 2: 1: 87$ by volume; $1 \mathrm{ml}$ of this suspension is cleared by $5.4 \mu \mathrm{g}$ hydrogen cyanide.
} 


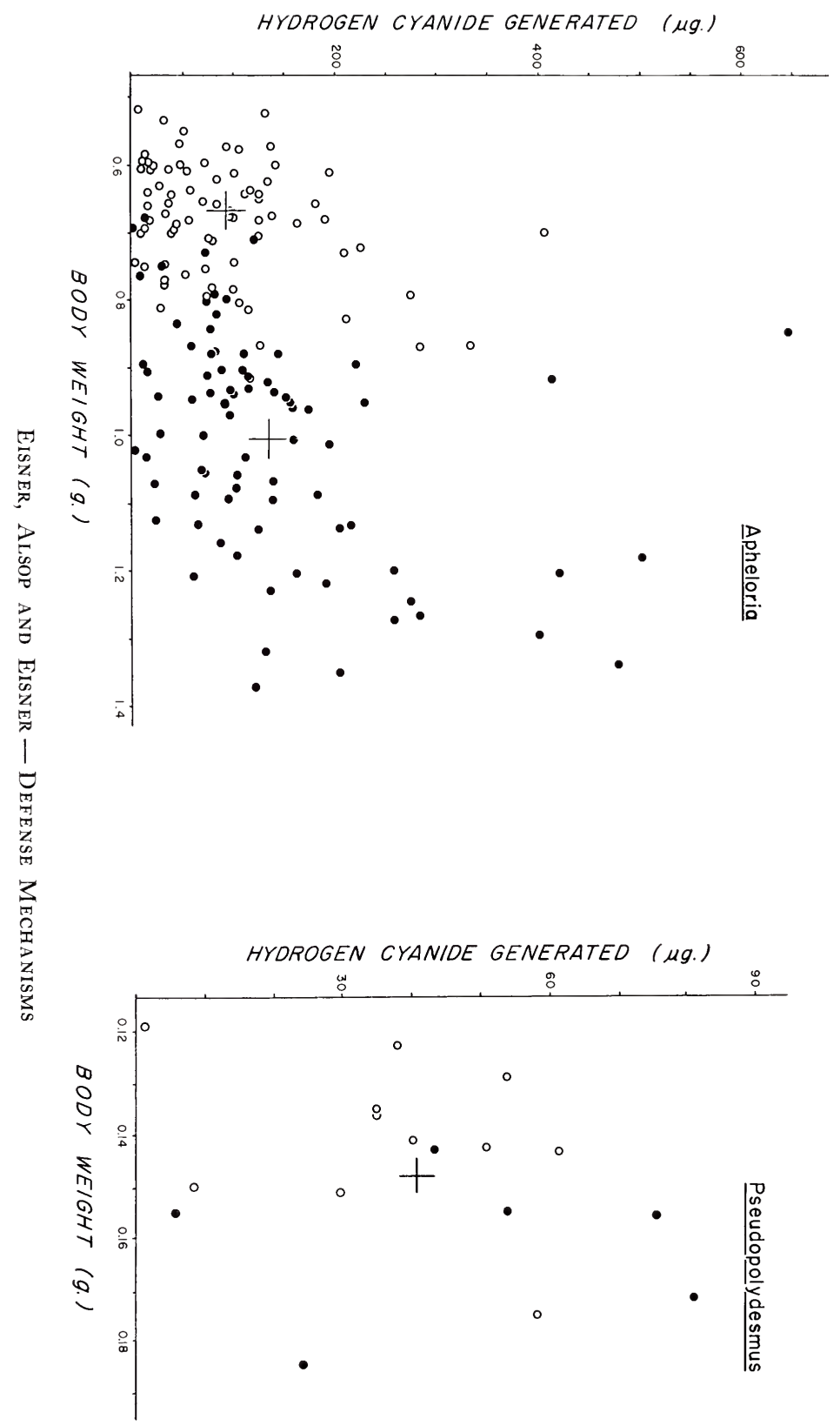


water as the standard ${ }^{ \pm}$. The assay was accurate to $\pm 0.6 \mu \mathrm{g}$ hydrogen cyanide, as was determined by measuring the efficiency of recovery of known amounts of hydrogen cyanide, generated in the apparatus by reaction of sodium cyanide and acid.

\section{RESULTS AND CONCLUSIONS}

A total of 157 adult Apheloria were tested, comprising 80 females and 77 males. Of Pseudopolydesmus, only I I males and 6 females were assayed. The results, plotted as hydrogen cyanide produced against body weight of millipede, are presented separately for each species in Plate 16.

Cyanogenetic yield is evidently a markedly variable parameter in both species. Apheloria, which is larger than Pseudopolydesmus, has a higher mean yield than the latter (I I $4 \mu \mathrm{g}$ /animal in Apheloria; 4I $\mu \mathrm{g}$ /animal in Pseudopolydesmus). Yet Pseudopolydesmus has more than twice the mean output per unit body weight than does Apheloria $(280 \mu \mathrm{g} / \mathrm{g}$ in Pseudopolydesmus; $135 \mu \mathrm{g} / \mathrm{g}$ in Apheloria).

In Apheloria, females tend to outproduce males; since females are also larger than males (note in Plate $\mathrm{I} 6$ the almost disjunct size distribution of the sexes) they probably have larger glands. Additional data might have shown the same to hold for Pseudopolydesmus.

Both species have considerable toxic potential, certainly at their higher levels of output. For example, a single Apheloria, weighing one gram and having a near maximum yield of $600 \mu \mathrm{g}$ of hydrogen cyanide, produces the equivalent of 18 times the Lethal Dose of a $300 \mathrm{~g}$ pigeon, 6 times the LD of a $20 \mathrm{~g}$ mouse, 0.4 times the LD of a $25 \mathrm{~g}$ frog, and O.OI times the LD of man (Flury and Zernik,

\footnotetext{
${ }^{4}$ The shunting of the gas stream from one trap to the next sometimes occurred slightly after, rather than before actual clearness had been achieved. As a result, individual traps could contain more cyanide (as ammonium cyanide, bound to the excess ammonia in the suspension) than the predictable amount that had solubilized the silver iodide. The pooled sample was therefore sometimes clear rather than turbid. This necessitated the addition, before backtitration with sodium cyanide, of sufficient fresh suspension to bring about a reappearance of turbidity, thus insuring the conversion of all cyanide to silver ammonium cyanide. Such added suspension was tallied as part of the total in the final computation.
}

\section{Explanation of Plate 16}

Cyanogenetic yield of individual Apheloria (left) and Pseudopolydesmus (right), plotted against body weight (males, open circles; females, closed circles). In Apheloria, mean yield (horizontal bar of crosses) and mean body weight (vertical bar of crosses) differs significantly $(\mathrm{p}<0.01)$ in the two sexes. In Pseudopolydesmus, due to the relatively scant data, mean output and weight are given for the population as a whole (single cross). 
I935; Stecher et al., I960). For a small, appropriately sensitive predator, swallowing Apheloria may well have its deleterious aftereffects. However, predators do not usually consume Apheloria, but are repelled by the secretion and its vapors. Under such circumstances, exposure to hydrogen cyanide and systemic incorporation of the poison are likely to be minimal. It is by no means clear how hydrogen cyanide, as a dilute vapor, effects its repellent action. The possibility that it acts in conjunction (synergistic ?) with the aldehyde should not be dismissed.

The cyanogenetic capacity of a millipede can be expressed in terms of the amount of cyanohydrin stored. A medium-sized Apheloria $(1 \mathrm{~g})$ with a near maximum generating capacity of $600 \mu \mathrm{g}$ hydrogen cyanide, has an effective defensive payload of $3.0 \mathrm{mg}$ mandelonitrile, or about $0.3 \%$ of body weight. Distributed equally among the animal's 22 glands, this amounts to an individual glandular load of O.I $3 \mathrm{mg}$ (ca. O.I $2 \mu \mathrm{l}$ ) or about I $2 \%$ of the estimated volume ( I $\mu \mathrm{l}$ ) of the reservoir of a gland. Given its emulsified state, mandelonitrile could be expected to occupy only a fraction of the total volume of the reservoir.

Attempts were made with Apheloria to determine the rate at which the contents of their glands are restored. Fifteen millipedes, reassayed within 8 days or less after initial depletion of their secretion, produced less than I $5 \mu \mathrm{g}$ hydrogen cyanide each. Another group of six, reassayed after 2 months, still had relatively low yield of 20 to IOO $\mu \mathrm{g}$. Secretion is thus seen to be synthesized at a slow and somewhat variable rate. ${ }^{5}$ Millipedes reassayed after four and five months produced little more than those reassayed after two months. However, this may reflect the fact that after two months the health of laboratory animals declined (as reflected by a sharp rise in mortality) and that their rate of secretory synthesis had become subnormal. Pseudopolydesmus apparently also reloads its glands slowly. When individuals that had been previously stimulated to depletion were subjected to rough handling several days later, they failed to give off the noticeable odor that is indicative of a discharge.

In view of the slow rate of synthesis of secretion, it is clear that in the four days or less that elapsed between capture and first assay the individual millipedes could not have added substantially to their secretory resources. The variability in output depicted in Plate 16 is therefore probably a fair representation of the actual variability that

\footnotetext{
${ }^{5} \mathrm{No}$ correlation was apparent between the magnitude of the initial yield and that subsequently obtained on reassay (a high initial output was sometimes followed by a relatively slow rate of synthesis, and vice versa).
} 
prevails in nature. Apheloria collected early in the season (first week of May) had as variable an output as those collected in midsummer or late November. In Pseudopolydesmus, output was also broadly variable on the two occasions that the species was collected (May and October). One wonders about the meaning of this variability. The fact that most millipedes have a yield that is considerably below the maximum recorded for their species might be taken to indicate that their glands are in a state of partial depletion and that encounters with predators are commonplace throughout the season. However, cyanogenetic potential may also be subject to instrinsic variation, and a submaximal yield need not by necessity reflect a history of past assault. Attempts to raise Apheloria in the laboratory in order to determine whether in the absence of predation their cyanogenetic potential achieves uniformity at high levels met with failure.

In an undisturbed millipede, there is no detectable spontaneous loss of hydrogen cyanide. Assays performed on groups of five millipedes, confined undisturbed in chamber $A$ of the apparatus for up to two days, invariably proved negative. Thus, the valve that ordinarily seals the connection between the two compartments of each gland

\begin{tabular}{|lc|}
\multicolumn{1}{c|}{ Organism } & \multicolumn{1}{c|}{$\begin{array}{c}\text { Cyanogenetic } \\
\text { Capacity } \\
\mu \mathrm{g} / \mathrm{g}\end{array}$} \\
\hline $\begin{array}{l}\text { Prunus serotina } \\
\text { (Wild black cherry) }\end{array}$ & 2100 \\
\hline $\begin{array}{l}\text { Prunus amygdalus } \\
\text { (Bitter almonds) }\end{array}$ & 1800 \\
\hline $\begin{array}{l}\text { Triglochin sp. } \\
\text { (Arrowgrass) }\end{array}$ & 500 \\
\hline $\begin{array}{l}\text { Bahia oppositifolia } \\
\text { (Bahia grass) }\end{array}$ & 300 \\
\hline Pseudopolydesmus serratus & 135 \\
\hline Apheloria corrugata & 280 \\
\hline
\end{tabular}

Table I. Mean cyanogenetic output of Pseudopolydesmus and Apheloria, compared with some of the higher cyanogenetic capacities recorded for plants (compiled from references in Kingsbury, 1964, and Wokes and Willimott, 1951). 
(text-fig. 2) and prevents the contents from interacting, must be virtually leak proof. Lack of output under these conditions also demonstrates that casual contact with other millipedes, such as occurred almost continuously during confinement in the chamber, does not constitute an appropriate stimulus for the discharge.

Cyanogenesis in animals is rare, and so far as known is restricted to polydesmoid millipedes and certain moths (Jones et al., I962). But among plants it is widespread, and occurs in several hundred species of diverse families (Seifert, 1955). The mechanism in plants may also be defensive, since as a rule the liberation of hydrogen cyanide is initiated only in response to injury. Cyanogenetic capacity of plants has been measured, and found to vary over a broad range. Mean output in Apheloria and Pseudopolydesmus is below the upper range of values recorded from plants (Table I). However, this comparison is of only limited significance. The values for plants are usually obtained by measuring the cyanide released after complete trituration of whole plants or parts thereof. Actual amounts liberated spontaneously by a plant for defensive purposes - as, for instance, when an insect bites into one of its leaves - has never been measured. The technique described here may be sufficiently sensitive to be employed for this purpose.

\section{SUMMARY}

I. A simple photometric assay for hydrogen cyanide is described, sensitive to $0.6 \mu \mathrm{g}$.

2. The assay was used to measure the cyanogenetic output of the defensive glands of two species of polydesmoid millipedes, Apheloria corrugata and Pseudopolydesmus serratus.

3. Output is highly variable in both species. Mean yield is I I $4 \mu \mathrm{g}$ HCN in Apheloria, and $4 \mathrm{I} \mu \mathrm{g}$ HCN in Pseudopolydesmus. Recorded maxima for each species are, respectively, 645 and 8i $\mu \mathrm{g} \mathrm{HCN}$.

4. The assay should prove useful for measuring cyanogenesis in other organisms, including plants.

\section{REFERENCES CITED}

Davenport, D., D. M. Wooton and J. E. Cushing.

1952. The biology of the Sierra luminous millipede, Luminodesmus sequoiae Loomis and Davenport. Biol. Bull. 102: 100-110.

DENIGÈs, G.

1895. Sur une nouvelle méthode cyanimérique et sur les applications qui en derivent. Ann. Chim. Phys. 7th ser. 6: 381-428. 
EIsner, H. E., T. EIsner and J. J. Hurst.

1963. Hydrogen cyanide and benzaldehyde produced by millipedes. Chem. and Ind. 1963: 124-125.

Eisner, T., H. E. Eisner, J. J. Hurst, F. C. Kafatos and J. Meinwald.

1963. Cyanogenic glandular apparatus of a millipede. Science 139: 1218-1220.

EISNER, T. AND H. E. EISNER.

1965. Mystery of a millipede. Nat. History 74: 30-37.

Eisner, T. and J. Meinwald.

1966. Defensive secretions of arthropods. Science 153: 13+1-1350.

FEIGL, F.

1960. Spot Tests in Organic Analysis. Elsevier, New York, p. 365.

FLURY, F. AND F. ZERNIK.

1935. Zusammenstellung der toxischen und letalen Dosen für die gebräuchlichsten Gifte und Versuchstiere, pp. 1289-1422. In Abderhalden, E. (ed.), Handbuch der Biologischen Arbeitsmethoden, part IV (7B), Urban \& Schwartzenberg, Berlin.

JaCoBson, $M$.

1966. Chemical insect attractants and repellents. Ann. Rev. Entomol. 11: 403-422.

Jones, D. A., J. Parsons, and M. Rothschild.

1962. Release of hydrocyanic acid from crushed tissue of all stages in the life-cycle of species of the Lygaeninae (Lepidoptera). Nature 193: 52-53.

Kingsbury, J. M.

1964. Poisonous Plants of the United States and Canada, Prentice-Hall, Englewood Cliffs, N. J.

Liebig, J.

1851. Verfahren zur Bestimmung des Blausäuregehaltes der medicinischen Blausäure, des Bittermandel- und Kirschlorbeerwassers. Ann. Chem. Pharm. 77: 102-114.

Roth, L. M. ANd T. EISNER.

1962. Chemical defenses of arthropods. Ann. Rev. Entomol. 7: 107-136.

Schildknecht, H., K. Holoubek, K. H. Weis and H. Kramer.

1964. Defensive substances of arthropods, their isolation and identification. Angew. Chem. 3: 73-82.

SeIfERT, P.

1955. Blausäure-Verbindungen, pp. 676-688. In Paech, K. and M. W. Tracey (eds.), Modern Methods of Plant Analysis, vol. IV, Springer, Berlin.

Stecher, P. G., M. J. Finkel and O. H. Siegmund.

1960. The Merck Index, Merck \& Co., Rahway, N. J., p. 534.

WoKes, F. and S. G. WillimotT.

1951. The determination of cyanide in seeds. J. Pharm. Pharmacol. 3: 905-916. 


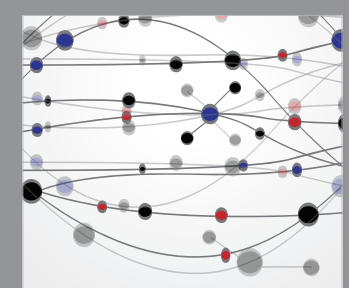

The Scientific World Journal
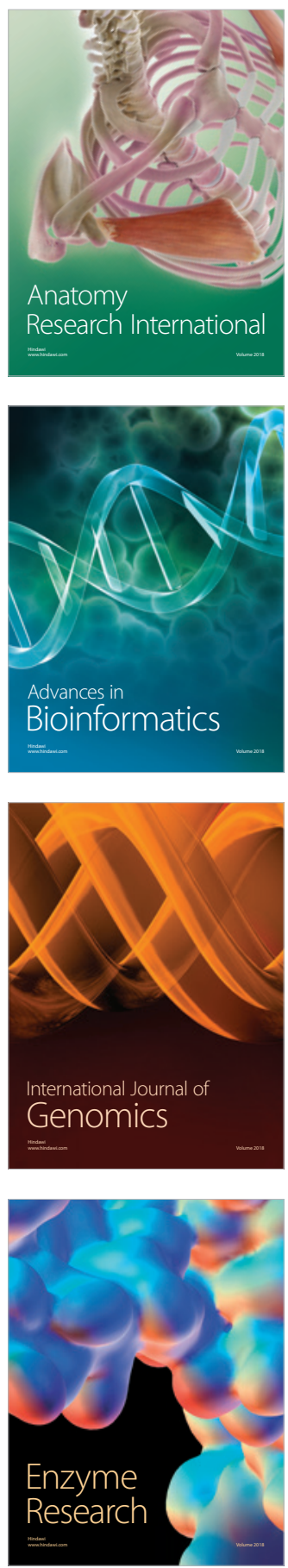
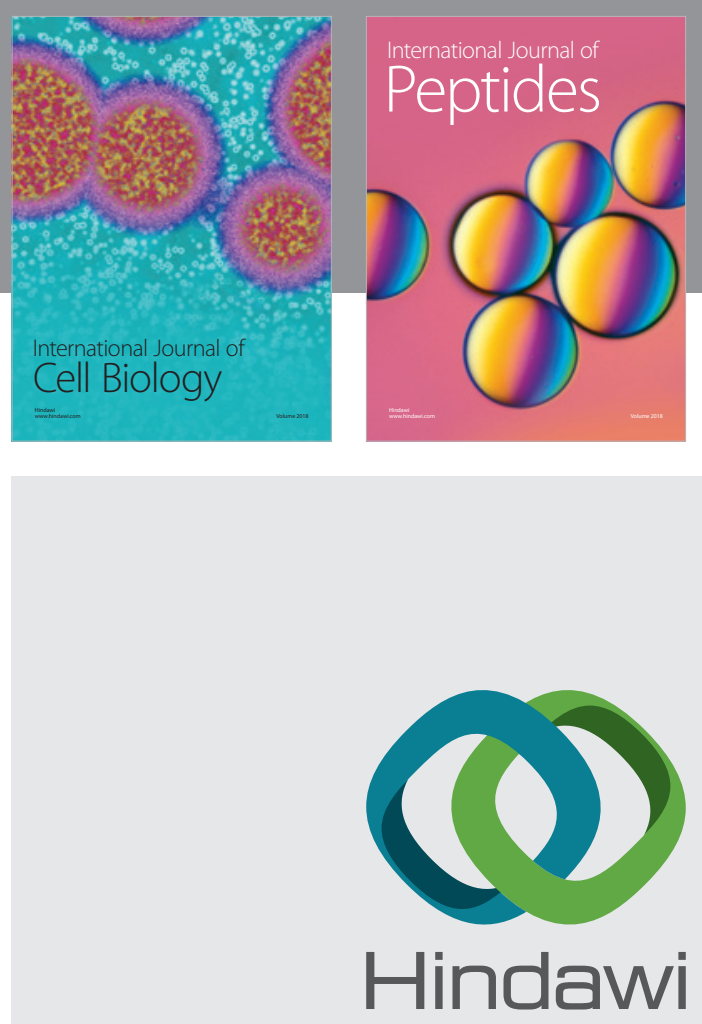

Submit your manuscripts at

www.hindawi.com
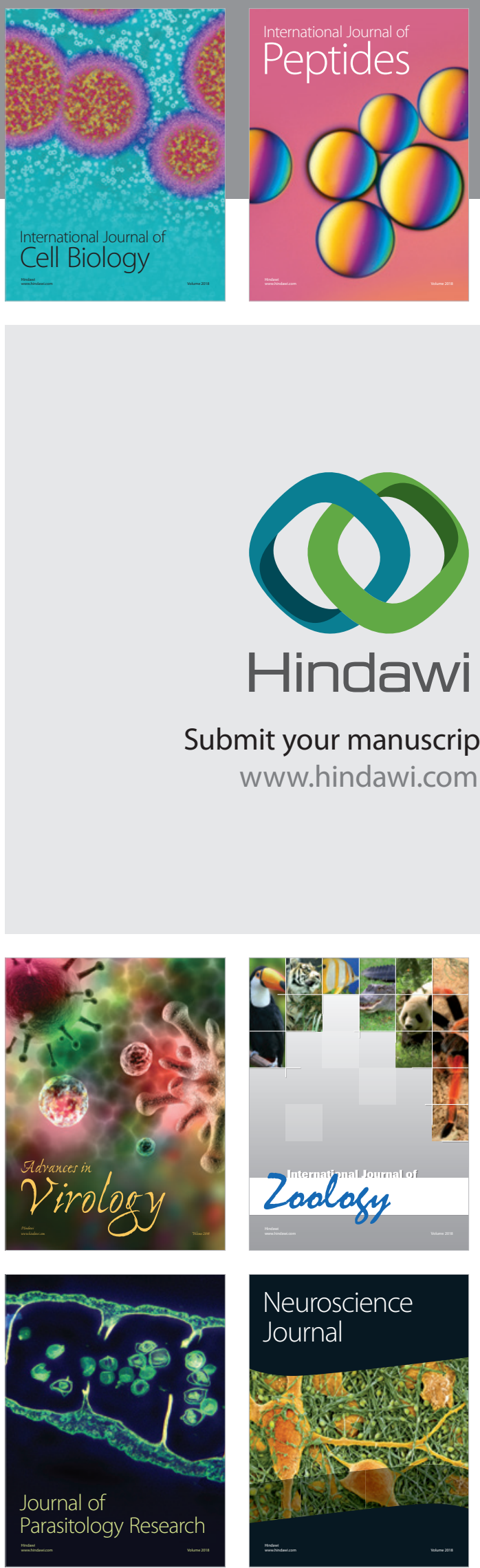
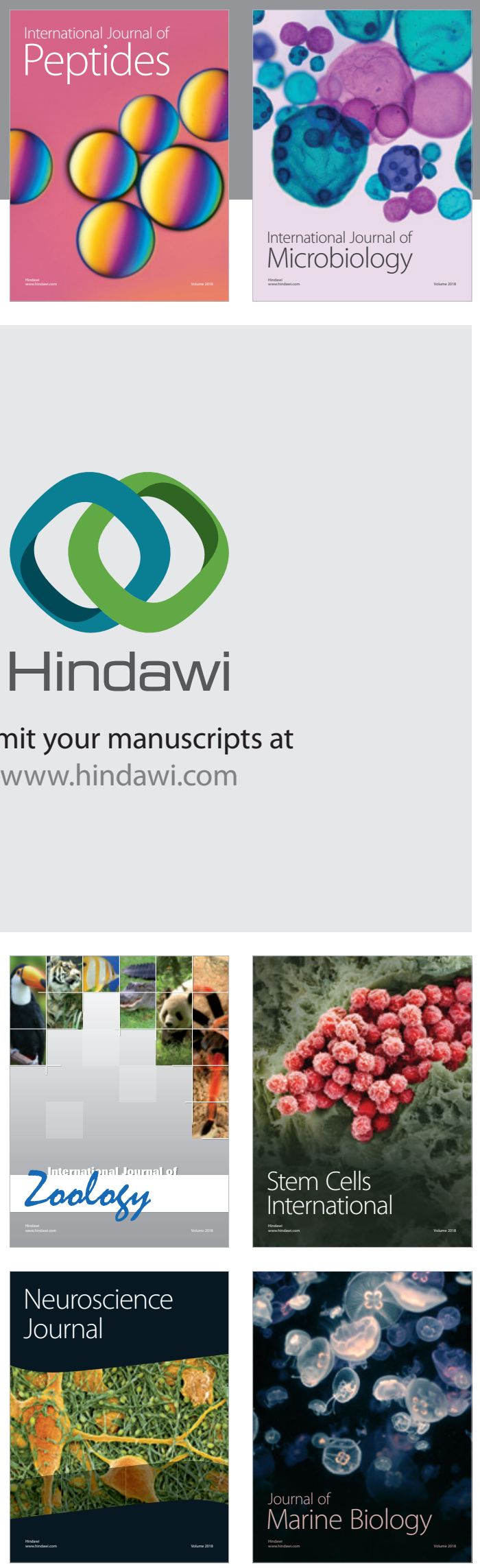
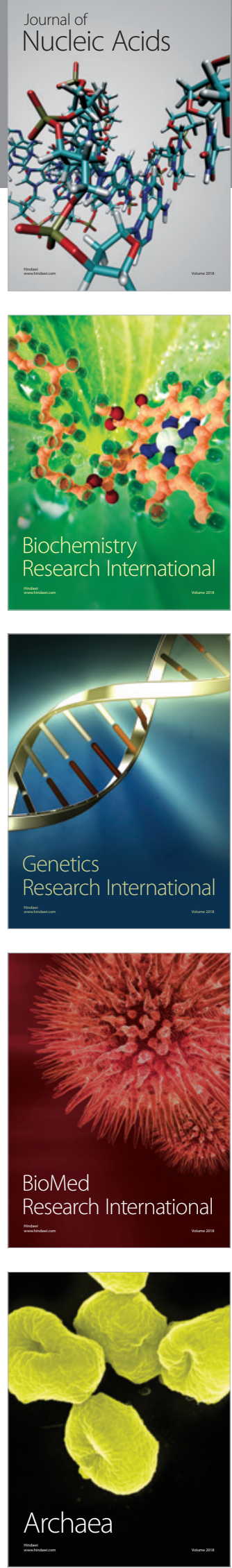